\title{
Development of a functional cake formulation with purple carrot powder dried by different methods
}

\section{Nezahat OLCAY, Mine ASLAN, Mustafa Kürşat DEMIIR, Nilgün ERTAŞ}

Cite this article as:

Olcay, N., Aslan, M., Demir, M.K., Ertaş, N. (2021). Development of a functional cake formulation with purple carrot powder dried by different methods. Food and Health, 7(4), 242-250. https://doi.org/10.3153/FH21025

Department of Food Engineering, Engineering and Architecture Faculty, Necmettin Erbakan University, Köyceğiz Campus, Konya, 42050, Turkey

RCID IDs of the authors: N.O. 0000-0003-3302-8969 M.A. 0000-0002-7589-3523 M.K.D. 0000-0002-4706-4170 N.E. 0000-0002-0671-2485

Submitted: 02.03 .2021

Revision requested: 29.03 .2021

Last revision received: 01.04 .2021

Accepted: 03.04.2021

Published online: 17.07.2021

Correspondence:

Nezahat OLCAY

E-mail: olcaynezahat@gmail.com

\begin{abstract}
In this study, it was aimed to enhanced cake formulation with purple carrot powder (PCP) dried 3 different methods (hot-air (HPC), microwave (MPC) and vacuum (VPC) dried) and used at 5 different ratios $(0,5,10,15,20 \%)$. The effects of purple carrot powder (PCP) on chemical, physical and sensory properties of cake samples were investigated. HPC substituted cake samples had lower batter density and weight values. PCP usage significantly affected the crust and crumb color value of cake samples $(\mathrm{p}<0.05)$. Samples containing MPC had higher firmness and lower springiness than others. Lower firmness, volume index, saturation index and higher springiness values were determined with increasing PCP rate. The highest total phenolic content and antioxidant activity were found in cake samples containing HPC and VPC, respectively. When all cake samples evaluated, the higher overall acceptability scores were obtained with HPC added cake samples at 15 and $20 \%$ substitution level compared to control sample.
\end{abstract}

Keywords: Hot-air drying, Microwave drying, Vacuum drying, Purple carrot, Cake

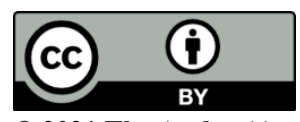

(C) 2021 The Author(s)

Available online at

http://jfhs.scientificwebjournals.com 


\section{Introduction}

Purple carrot (Daucus carota L.) is an important root vegetable in human nutrition and mostly grown in Turkey. The purple carrots have a strong antioxidant activity due to anthocyanin content (17.4 to $45.4 \mathrm{~g} / \mathrm{kg}$ in dry matter) (Türkyılmaz et al., 2012). Phenolic components and anthocyanin rich purple carrot also has beneficial effects on health-promotion or disease prevention. Moreover, the carrot has different important biological properties such as antioxidants, anticarcinogen, immunoenhencer, antidiabetic, anti-hypertensive cholesterol and cardiovascular diseases lowering effects (Yerima et al., 2019).

Cereal products have valuable protein and carbohydrate content, although they are lack of antioxidant compounds compared to fruit and vegetables. Researchers have focus on formulation of cereal products by fruit-vegetable powders. Fruitvegetables have a short shelf life due to high water content, thus they are generally dried for a long shelf life. Drying is one of the most important and common food preservation technique. Various drying methods are applied for dehydration of water in products as microwave drying, hot-air drying and vacuum drying for dehydration of water in products (Jangam, 2011).

Hot-ait drying is a common and low cost application when compared to other drying methods. However, hot-air drying has some disadvantages including longer drying time, undesirable physical, chemical, structural properties and higher nutritional loss and these features causes to decrease quality and consumer acceptability of end product (Di Scala and Crapiste, 2008; Arslan and Özcan, 2011; Chen et al., 2016). On the other hand, microwave drying has some advantages as a shorter drying period and low energy consumption, and also some disadvantages like irregular heating, possible textural damage and high investment costs (Zhang et al., 2006; Iş1k and Izlin, 2014). Vacuum drying enhances the mass transfer due to the increased pressure gradient in the product. Vacuum drying is supplied several properties such as better product color and protections of vitamin, lower process temperatures and energy (Pere and Rodier, 2002; Methakhup et al., 2005; Alibaş, 2009).

New functional food formulations which have ingredients with high phenolic content and antioxidant activity have attention increasingly. Thus, the aim of this study was to determine the chemical composition, physical and sensory properties of cake products containing purple carrot powders dried by different methods. Also, it was aimed to determine PCP applications as a potential ingredient in the development of new food products.

\section{Materials and Methods}

\section{Materials}

Wheat flour, whole egg, sugar, all-purpose shortening, skimmed milk powder, baking powder and purple carrot were purchased from local markets in Konya, Turkey.

\section{Drying of Purple Carrot}

Firstly, the purple carrots were washed, peeled and sliced with the size of $2 \mathrm{~mm}$. For the hot-air drying method, samples were dried in a hot air oven (KD 200, Nüve, Turkey) at $50^{\circ} \mathrm{C}$ for $22 \mathrm{~h}$. For the microwave drying method, samples were dried in a microwave oven (LG SolarDOM, MP-9485, Seul, South Korea) at $360 \mathrm{~W}$ for $40 \mathrm{~min}$. For the vacuum drying method, samples were dried in a vacuum oven (JSR, JSVO$60 \mathrm{~T}$, Gongju, South Korea) at $50^{\circ} \mathrm{C}$ for $10 \mathrm{~h}$. The dried purple carrots were ground and sieved with $500 \mu \mathrm{m}$ sieve to obtain purple carrot powder (PCP).

\section{Cake Production}

Cake production was carried out with slight modification according to the method of Rahmati and Tehrani (2014). Control cake sample prepared with $100 \mathrm{~g}$ flour, $50 \mathrm{~g}$ shortening, $75 \mathrm{~g}$ sugar, $60 \mathrm{~g}$ egg, $70 \mathrm{ml}$ milk, $0.2 \mathrm{~g}$ salt, $3 \mathrm{~g}$ baking powder, $1 \mathrm{~g}$ vanilla, $0.5 \mathrm{~g}$ DATEM (diacetyl tartaric acid esters of monoglycerides and diglycerides) and $0.5 \mathrm{~g}$ xanthan gam. Other cake samples were made by replacing wheat flour with PCP (HPC, MPC and VPC) at 0, 5, 10, 15 and 20\% ratio. Firstly, egg and sugar were whipped to a cream in a Hobart mixer (Hobart N50, Canada Inc., North York, Ontario, Canada). Then, other ingredients were added and mixed. 130 grams of cake batter were placed into baking pans with $7.5 \times 6.6 \times 12 \mathrm{~cm}$ dimensions, and baked at $160 \pm 2^{\circ} \mathrm{C}$ for $50 \mathrm{~min}$ in an oven (BEKO MF6, Turkey). Finally, baked cake samples were removed from the pan and left for one-hour cooling. Cake samples were packaged and stored at room temperature $\left(22 \pm 2^{\circ} \mathrm{C}\right)$ until analyses.

\section{Cake Batter Analyses}

Cake batter $\mathrm{pH}$ was measured with a suspension obtained from $10 \mathrm{~g}$ dough with $90 \mathrm{~mL}$ distilled water for 1 min using a digital $\mathrm{pH}$ meter (WTW pH315i/set). Cake batter density was calculated by dividing the weight of a standard measure of the batter by the weight of an equal volume of water (Jyotsna et al., 2007).

\section{Physical Analysis}

Color values ( $L^{*}$ (lightness/darkness), $a^{*}$ (redness/greenness) and $b^{*}$ (yellowness/ blueness)) of PCP and cake samples were determined by Chroma Meter CR-400 (Konica Minolta, 
Sensing, Inc., Osaka, Japan). Chroma (SI) $\left(\mathrm{SI}=\sqrt{a *^{2}+b *^{2}}\right)$ and hue angle $(\mathrm{H}=\tan -1(b * / a *))$ of cake samples were calculated from $a^{*}$ and $b^{*}$. The weight of cake samples was measured by weighing the one hour cooled cakes at room temperature. Symmetry, volume and uniformity indexes were calculated according to the AACC 1091 method (AACC, 1990). Firmness and springiness of cake samples were measured by a texture analyzer instrument (TA-XT plus, Stable Microsystems, UK) at room temperature, and was used an aluminum P36/R cylinder as the probe. The optimal test conditions in this study were: strain was $25 \%$, and the pre-test, test and post-test speeds were 1.0, 1.0 and $10.0 \mathrm{~mm} / \mathrm{s}$, respectively. Cake samples were packaged in polyethylene bags and stored at room conditions $\left(22 \pm 2{ }^{\circ} \mathrm{C}\right.$, $45 \% \pm 10 \mathrm{RH}$ ) during storage.

\section{Chemical Analysis}

Moisture (AACC 44-01), protein (AACC 46-12), fat (AACC 30-10) contents of different purple carrot powders and cake samples were analyzed according to the standard methods of AACC (1990). For total phenolic content and antioxidant activity, $4 \mathrm{~g}$ sample was extracted with $20 \mathrm{~mL}$ acidified $(1 \%$ $\mathrm{HCl})$ methanol/water solution $(80: 10, \mathrm{v} / \mathrm{v})$ at $24{ }^{\circ} \mathrm{C}$ for $2.5 \mathrm{~h}$. Sample: extraction solution mixture was shaken in water bath at room temperature $\left(24 \pm 1^{\circ} \mathrm{C}\right)$ for 2.5 hours. After extraction, the samples were centrifuged at $3.000 \mathrm{rpm}$ for $10 \mathrm{~min}$ (Gao et al., 2002; Beta et al., 2005). Total phenolic content was determined spectrophotometrically using the Folin-Ciocalteu method and the results were reported as $\mathrm{g} / \mathrm{kg}$ gallic acid equivalents (GAE) of sample on a dry matter basis. Antioxidant activity analysis was carried out according to the DPPH (2-2-Diphenyl-2-picrylhydrazyl) method (Gyamfi et al., 1999; Beta et al., 2005). This results were determined by the following equation;

Inhibition $(\%)=[($ Absorbance of control- Absorbance of sample)/ Absorbance of control] $\times 100$

\section{Sensory Analysis}

Color, odor, taste, appearance, pore structure, chewiness and overall acceptability of cake samples were evaluated by 10 panelists of 25-30 age. The cake samples were randomly named with different numerical codes. Panelists have evaluated the samples with a scale from 1 (dislike extremely) to 7 (like extremely).

\section{Statistical Analysis}

For the statistical analysis, the JMP statistical program, version 10.0 (SAS Institute Inc., Cary, NC, USA) was used. The average of the main variation sources was compared at $\mathrm{p}<0.05$ level.

\section{Results and Discussion}

\section{Physical and Chemical Properties of Purple Carrot Powders}

Color values and some chemical properties of wheat flour and PCP dried with different drying methods are demonstrated in Table 1. $L^{*}$ values of PCP changed between 41.46 (for VPC) and 48.22 (for HPC). As expected, the highest $L^{*}$ value was found in wheat flour, while hot air drying had the most positive effect on the $L^{*}$ value of PCP. The $a^{*}$ and $b^{*}$ values of PCP depending on drying methods were found to be statistically different. The $a^{*}$ value of wheat flour was found to be significantly lower than those of PCP, while the $b^{*}$ value was higher. Chroma and hue angle values of PCP in all drying methods found higher than wheat flour. Regarding the drying methods used, higher chroma values obtained with HPC, while higher hue angle values found with VPC. De Pilli et al. (2014) investigated the effect of microwave and hot air drying on pasta samples and reported that microwave dried samples had higher hue angle and lower chroma values against hot air dried ones. It was reported that high values of hue angle and low values of chroma value were related to the degradation of carotenoids.

It was determined that the crude ash content of PCP was higher than wheat flour. The highest crude ash content was determined in HPC. The crude fat content of wheat flour was significantly higher than PCP. All drying methods provided similar crude fat contents in PCP samples. No significant differences occurred in the crude protein content of the wheat flour and PCP ( $>>0.05)$. The total phenolic content of the hot air dried and microwave dried samples were found to be statistically similar. As expected, the TPC of purple carrots was significantly higher than wheat flour. The antioxidant activity of PCP ranged between $63.68 \%$ (for HPC) and $85.87 \%$ (for VPC). As expected, the antioxidant activity of PCP was determined to be much higher than that of wheat flour.

\section{Some Properties of Cake Batters}

Some properties of cake batters are shown in Table 2. Higher substitution rates led to lower $\mathrm{pH}$ values in cake batters. Zadernowski et al. (2010) reported that black carrot has 14.80 $\mathrm{mg} / 100 \mathrm{~g}$ vitamin $\mathrm{C}$ content in dry matter. The $\mathrm{pH}$ values of cake batters produced with VPC were found to be higher than the batters produced with HPC and WPC. The weights of cake batters produced with VPC were found to be higher than others. The utilization of HPC has resulted in significantly lower density $\left(1.04 \mathrm{~g} / \mathrm{cm}^{3}\right)$. It was found that there was a linear relationship between the substitution rate, weight and density. Increased substitution rates resulted in increased weight and density. Sharoba et al. (2013) mentioned that the 
addition of dietary fiber sources like carrot pomace to wheat flour to produced cake increased the water holding capacity. Increased weight and density could see as a result of increased water holding capacity. Consistent with these results,
Salehi et al. (2015) and Majzoobi et al. (2016) reported that increase of density value and decrease of $\mathrm{pH}$ value with high replacement ratio of carrot powder, respectively.

Table 1. Color values and chemical properties of wheat flour and purple carrot powders dried by different methods

\begin{tabular}{lcccc}
\hline & Wheat Flour & HPC & MPC & VPC \\
\hline Color values & & & & \\
$L^{*}$ & $95.31 \pm 0.01 \mathrm{a}$ & $48.22 \pm 0.09 \mathrm{~b}$ & $43.32 \pm 0.11 \mathrm{c}$ & $41.46 \pm 0.02 \mathrm{~d}$ \\
$a^{*}$ & $-0.30 \pm 0.01 \mathrm{c}$ & $16.32 \pm 0.11 \mathrm{a}$ & $14.48 \pm 0.01 \mathrm{~b}$ & $14.53 \pm 0.28 \mathrm{~b}$ \\
$b^{*}$ & $10.26 \pm 0.01 \mathrm{a}$ & $-1.68 \pm 0.10 \mathrm{~d}$ & $-0.57 \pm 0.01 \mathrm{c}$ & $1.66 \pm 0.04 \mathrm{~b}$ \\
Chroma & $10.26 \pm 0.01 \mathrm{c}$ & $16.40 \pm 0.12 \mathrm{a}$ & $14.50 \pm 0.01 \mathrm{~b}$ & $14.62 \pm 0.28 \mathrm{~b}$ \\
Hue Angle & $-88.30 \pm 0.04 \mathrm{~d}$ & $-5.88 \pm 0.31 \mathrm{c}$ & $-2.25 \pm 0.05 \mathrm{~b}$ & $6.54 \pm 0.26 \mathrm{a}$ \\
Moisture (\%) & $11.46 \pm 0.05 \mathrm{a}$ & $5.83 \pm 0.10 \mathrm{c}$ & $4.22 \pm 0.23 \mathrm{~d}$ & $7.02 \pm 0.28 \mathrm{~b}$ \\
Ash (\%) & $0.62 \pm 0.01 \mathrm{~d}$ & $11.04 \pm 0.04 \mathrm{a}$ & $8.60 \pm 0.01 \mathrm{~b}$ & $8.18 \pm 0.08 \mathrm{c}$ \\
Crude Fat (\%) & $1.18 \pm 0.02 \mathrm{a}$ & $0.75 \pm 0.11 \mathrm{~b}$ & $0.72 \pm 0.04 \mathrm{~b}$ & $0.71 \pm 0.02 \mathrm{~b}$ \\
Crude Protein (\%) & $11.20 \pm 0.12 \mathrm{a}$ & $11.33 \pm 0.31 \mathrm{a}$ & $10.94 \pm 0.25 \mathrm{a}$ & $11.29 \pm 0.37 \mathrm{a}$ \\
TPC $($ g GAE/kg) & $25.57 \pm 0.35 \mathrm{c}$ & $279.10 \pm 0.70 \mathrm{a}$ & $276.39 \pm 3.13 \mathrm{a}$ & $263.36 \pm 1.39 \mathrm{~b}$ \\
Antioxidant activity (\%) & $15.72 \pm 0.12 \mathrm{~d}$ & $63.68 \pm 0.43 \mathrm{c}$ & $76.74 \pm 0.03 \mathrm{~b}$ & $85.87 \pm 0.01 \mathrm{a}$ \\
\hline
\end{tabular}

Results are expressed as mean value \pm s.d. Different superscripted lowercase letters in the same column denote significant differences according to the Tukey HSD test $(p<0.05)$. HPC: Purple carrot powder dried by hot air drying, MPC: Purple carrot powder dried by microwave drying, VPC: Purple carrot powder dried by vacuum drying. 1: Total Polyphenolic Content.

Table 2. Some properties of cake batters substituted with purple carrot powders

\begin{tabular}{lccc}
\hline & Weight $(\mathbf{g})$ & Density $(\mathbf{g} / \mathbf{m L})$ & $\mathbf{p H}$ \\
\hline Drying Method & & & \\
HPC & $107.51 \pm 0.49 \mathrm{~b}$ & $1.04 \pm 0.03 \mathrm{~b}$ & $6.91 \pm 0.04 \mathrm{~b}$ \\
MPC & $107.60 \pm 0.28 \mathrm{~b}$ & $1.47 \pm 0.04 \mathrm{a}$ & $6.89 \pm 0.05 \mathrm{~b}$ \\
VPC & $108.32 \pm 0.37 \mathrm{a}$ & $1.46 \pm 0.03 \mathrm{a}$ & $7.01 \pm 0.03 \mathrm{a}$ \\
\hline Substitution Rate & & & \\
0 & $106.85 \pm 0.35 \mathrm{~d}$ & $1.02 \pm 0.02 \mathrm{c}$ & $7.04 \pm 0.09 \mathrm{a}$ \\
5 & $107.05 \pm 0.49 \mathrm{~d}$ & $1.39 \pm 0.03 \mathrm{ab}$ & $6.96 \pm 0.04 \mathrm{~b}$ \\
10 & $107.80 \pm 0.14 \mathrm{c}$ & $1.40 \pm 0.05 \mathrm{ab}$ & $6.92 \pm 0.03 \mathrm{bc}$ \\
15 & $108.40 \pm 0.52 \mathrm{~b}$ & $1.38 \pm 0.03 \mathrm{~b}$ & $6.87 \pm 0.01 \mathrm{c}$ \\
20 & $108.95 \pm 0.40 \mathrm{a}$ & $1.43 \pm 0.04 \mathrm{a}$ & $6.90 \pm 0.02 \mathrm{bc}$ \\
\hline
\end{tabular}

Results are showed separate effects of drying methods and substitution rates of purple carrot powders which were added based on the wheat flour used (\% (by mass), dry basis). Results are expressed as mean value \pm s.d. Different superscripted lowercase letters in the same column denote significant differences according to the Student's test $(\mathrm{p}<0.05)$. 


\section{Physical Properties of Cake Samples}

Crust and crumb color values of cake samples substituted with HPC, MPC and VPC are given in Table 3. Among drying methods, $L^{*}$ values of cake crumbs substituted with HPC were positively affected by the drying method used. In the MPC added cake samples, $a^{*}$ values were lower and $b^{*}$ values were higher than other samples $(\mathrm{p}<0.05) . L^{*}$ and $b^{*}$ values of cake crumbs decreased, while $a^{*}$ values increased with the increasing substitution rate of PCP. Similar results were observed by Y1lmaz and Pekmez (2020) in bread samples incorporated with black carrot flour. Lower chroma and higher hue angle values were obtained with increased PCP substitution rates in cakes crumbs. It is probably due to the degradation of carotenoids (De Pilli et al., 2014).

There were no significant differences in $L^{*}$ values of cake crusts related to drying methods used ( $\mathrm{p}>0.05)$. The highest $a^{*}$ and $b^{*}$ values were determined in the cake crusts with substitution of VPC $(\mathrm{p}<0.05)$. All color parameters $\left(L^{*}, a^{*}\right.$ and $\left.b^{*}\right)$ of cake crusts were negatively affected by the increasing substitution rate. These results may be due to own color of PCP. It is known that crust color was basically determined by Maillard reactions between amino acids and reducing sugars, and by caramelization reactions of sugars (Gómez et al., 2011). Therefore, negative effects in crusts colors can be seen related to factors that affect such reactions as the $\mathrm{pH}$ of the batter. The $\mathrm{pH}$ values affect the amount of unprotonated amino acids and so inception stage of the Maillard reaction (Lertittikul et al., 2007; Gómez et al., 2011). Increase in substitution rate negatively affected the chroma and hue angle values of cake crusts.

Physical properties of cake samples prepared with HPC, MPC and VPC are given in Table 4. Firmness values of cakes substituted with MPC were highest on the first day of storage $(p<0.05)$. On the $3 r d$ day, it was seen that HPC had more negative effect than other samples on firmness values. Increasing substitution rate of PCP led to an increase in firmness values for both the first and third days. Hosseini Ghaboos et al. (2018) stated that firmness properties of cake production have changed as depending on the density of cake batter, and also cake texture characterization related to both the end-cake weight and the end-cake volume characterization. Also, Sharoba et al. (2013) who found that carrot pomace replacement led to an increase of firmness in cake samples, mentioned that thickening of the crumb cells surrounding the air spaces and molecular entanglements between fiber and gluten proteins led to higher firmness values. Similar results were observed by Hosseini Ghaboos et al. (2018) for sponge cake incorporation with pumpkin flour. MPC substitution had the most negative effect on the springiness values of cakes on the first day $(\mathrm{p}<0.05)$. This result can be due to the low moisture content of MPC (Table 1). Springiness values of all samples regardless of drying methods were negatively affected and decreased up to 3 rd day. In a study, springiness values of cake samples substituted with infrared-hot air dried carrot powder were decreased with an increased replacement ratio of cake flour (Salehi et al., 2015).

It was only substitution rate showed a significant effect on the volume index of cakes. Salehi et al. (2015) found that the volume value of sponge cake samples affected negatively with increased carrot powder ratio. The highest symmetry index found in samples produced with VPC $(22.10 \mathrm{~mm})$ and the lowest with MPC $(16.05 \mathrm{~mm})$. Similar to the volume index results, the symmetry indexes of cakes decreased with the increasing substitutions of PCP. No significant differences according to the drying method or substitution rate occurred in the uniformity index of the cake samples ( $p>0.05$ ).

\section{Chemical Properties of Cake Samples}

The chemical compositions of cake samples are shown in Table 5. During the drying of purple carrots, it is intended to be dried to a similar moisture level $(<10 \%)$ as much as possible. The moisture content of the cakes substituted with PCP depending on the substitution rate was found to be statistically similar. However, a slight by a significant difference between drying method was determined by Student's multiple comparison test. According to the results, the moisture content of samples dried with MPC was found to be significantly lower than those of HPC and VPC. This is a quite reasonable result owing to the fact that the moisture content of microwave dried purple carrots found lower than those of others (Table 1). The used drying methods were no significant influence on the crude ash contents of cake samples. But increased substitution rate was affected the crude ash content and resulted in an increase. Similar results were reported by Salehi et al. (2015) who investigated the usage potential of infrared-hot air-dried carrot in sponge cake. The crude fat content of samples had statistical differences depending on both drying methods and substitution rates. HPC substitution and increased rates had reducing effects on the crude fat content of samples. Uribe et al. (2019) who found that the crude fat content of vacuum-dried green seaweed was higher than the convection dried one reported that changes in fat content may be related to water loss. No significant differences determined in the crude protein content of cake samples regarding both drying methods and substitution rates $(p>0.05)$. 
Table 3. Color values of purple carrot substituted cake samples produced by different drying methods and substitution rates

\begin{tabular}{|c|c|c|c|c|c|c|c|c|c|}
\hline & & \multicolumn{3}{|c|}{ Drying Method } & \multicolumn{5}{|c|}{ Substitution Rate } \\
\hline & & HPC & MPC & VPC & $\mathbf{0}$ & 5 & 10 & 15 & 20 \\
\hline \multirow{5}{*}{ Crumb } & $L^{*}$ & $44.88 \pm 0.09 \mathrm{a}$ & $43.93 \pm 0.08 b$ & $44.17 \pm 0.29 b$ & $74.82 \pm 0.22 \mathrm{a}$ & $45.12 \pm 0.03 b$ & $39.14 \pm 0.10 \mathrm{c}$ & $32.45 \pm 0.09 \mathrm{~d}$ & $30.09 \pm 0.33 \mathrm{e}$ \\
\hline & $a^{*}$ & $5.25 \pm 0.13 \mathrm{a}$ & $4.77 \pm 0.14 b$ & $5.20 \pm 0.28 \mathrm{a}$ & $-2.07 \pm 0.03 \mathrm{e}$ & $5.29 \pm 0.08 \mathrm{~d}$ & $6.96 \pm 0.41 \mathrm{c}$ & $7.33 \pm 0.23 b$ & $7.85 \pm 0.18 \mathrm{a}$ \\
\hline & $b^{*}$ & $7.05 \pm 0.11 \mathrm{~b}$ & $7.74 \pm 0.12 \mathrm{a}$ & $6.61 \pm 0.31 \mathrm{c}$ & $28.14 \pm 0.11 \mathrm{a}$ & $4.79 \pm 0.31 b$ & $1.85 \pm 0.11 \mathrm{c}$ & $0.63 \pm 0.26 \mathrm{~d}$ & $0.25 \pm 0.12 \mathrm{e}$ \\
\hline & Chroma & $11.75 \pm 0.19 \mathrm{a}$ & $11.50 \pm 0.21 \mathrm{ab}$ & $11.47 \pm 0.30 \mathrm{~b}$ & $28.21 \pm 0.11 \mathrm{a}$ & $7.18 \pm 0.27 \mathrm{c}$ & $7.24 \pm 0.39 c$ & $7.37 \pm 0.22 \mathrm{c}$ & $7.86 \pm 0.17 b$ \\
\hline & Hue Angle & $-5.46 \pm 0.61 b$ & $-0.35 \pm 0.44 a$ & $-7.86 \pm 2.38 \mathrm{c}$ & $-85.79 \pm 0.04 \mathrm{e}$ & $41.25 \pm 1.39 \mathrm{a}$ & $14.68 \pm 1.58 \mathrm{~b}$ & $5.16 \pm 1.86 \mathrm{c}$ & $1.90 \pm 0.84 \mathrm{~d}$ \\
\hline \multirow{5}{*}{ Crust } & $L^{*}$ & $38.59 \pm 0.29 \mathrm{a}$ & $38.49 \pm 0.39 \mathrm{a}$ & $38.34 \pm 0.70 \mathrm{a}$ & $40.36 \pm 0.43 a$ & $39.21 \pm 0.65 b$ & $39.23 \pm 0.43 b$ & $36.97 \pm 0.41 \mathrm{c}$ & $36.58 \pm 0.37 \mathrm{c}$ \\
\hline & $a^{*}$ & $9.77 \pm 0.20 \mathrm{c}$ & $10.88 \pm 0.16 b$ & $11.24 \pm 0.33 \mathrm{a}$ & $12.36 \pm 0.60 \mathrm{a}$ & $11.42 \pm 0.18 b$ & $10.36 \pm 0.01 \mathrm{c}$ & $9.90 \pm 0.32 d$ & $9.10 \pm 0.03 \mathrm{e}$ \\
\hline & $b^{*}$ & $10.24 \pm 0.45 c$ & $12.98 \pm 0.27 b$ & $13.34 \pm 0.24 \mathrm{a}$ & $16.32 \pm 0.46 \mathrm{a}$ & $14.35 \pm 0.49 b$ & $12.16 \pm 0.20 \mathrm{c}$ & $10.00 \pm 0.30 \mathrm{~d}$ & $8.11 \pm 0.14 \mathrm{e}$ \\
\hline & Chroma & $14.20 \pm 0.27 \mathrm{c}$ & $16.99 \pm 0.13 b$ & $17.48 \pm 0.25 \mathrm{a}$ & $20.48 \pm 0.01 \mathrm{a}$ & $18.37 \pm 0.45 b$ & $16.00 \pm 0.15 \mathrm{c}$ & $14.08 \pm 0.39 \mathrm{~d}$ & $12.20 \pm 0.07 \mathrm{e}$ \\
\hline & Hue Angle & $45.45 \pm 1.51 \mathrm{~b}$ & $48.83 \pm 0.87 \mathrm{a}$ & $49.39 \pm 0.90 \mathrm{a}$ & $52.86 \pm 2.12 \mathrm{a}$ & $50.83 \pm 0.91 b$ & $49.12 \pm 0.54 c$ & $45.12 \pm 1.27 \mathrm{~d}$ & $41.51 \pm 0.62 \mathrm{e}$ \\
\hline
\end{tabular}

Results are showed separate effects of drying methods and substitution rates of purple carrot powders which were added based on the wheat flour used (\% (by mass), dry basis). Results are expressed as mean value \pm s.d. Different superscripted lowercase letters in the same column denote significant differences according to the Student's test ( $<0.05$ )

Table 4. Physical properties of purple carrot substituted cake samples produced by different drying methods and substitution rates

\begin{tabular}{|c|c|c|c|c|c|c|c|}
\hline & $\begin{array}{l}\text { Firmness (g) } \\
\text { 1. day }\end{array}$ & $\begin{array}{l}\text { Firmness (g) } \\
\text { 3. day }\end{array}$ & $\begin{array}{c}\text { Springiness (\%) } \\
\text { 1. day }\end{array}$ & $\begin{array}{c}\text { Springiness }(\%) \\
\text { 3. day }\end{array}$ & $\begin{array}{c}\mathrm{VI}^{1} \\
(\mathrm{~mm})\end{array}$ & $\begin{array}{c}\mathrm{SI}^{2} \\
(\mathrm{~mm})\end{array}$ & $\mathbf{U I}^{3}$ \\
\hline \multicolumn{8}{|l|}{ Drying } \\
\hline \multicolumn{8}{|l|}{ Method } \\
\hline $\mathrm{HPC}$ & $359.89 \pm 10.24 b$ & $734.42 \pm 21.66 \mathrm{a}$ & $52.13 \pm 0.80 \mathrm{a}$ & $45.08 \pm 1.11 \mathrm{a}$ & $146.80 \pm 2.55 \mathrm{a}$ & $18.80 \pm 3.11 \mathrm{ab}$ & $-1.00 \pm 4.67 \mathrm{a}$ \\
\hline MPC & $410.52 \pm 8.92 \mathrm{a}$ & $709.98 \pm 31.12 \mathrm{a}$ & $50.05 \pm 0.92 b$ & $44.36 \pm 0.60 \mathrm{a}$ & $147.30 \pm 3.54 \mathrm{a}$ & $16.05 \pm 4.03 b$ & $-1.15 \pm 4.45 a$ \\
\hline VPC & $346.54 \pm 23.21 \mathrm{~b}$ & $586.25 \pm 22.78 b$ & $51.62 \pm 1.21 \mathrm{a}$ & $45.19 \pm 0.88 \mathrm{a}$ & $145.45 \pm 3.46 \mathrm{a}$ & $22.10 \pm 1.84 \mathrm{a}$ & $-2.30 \pm 5.94 \mathrm{a}$ \\
\hline \multicolumn{8}{|c|}{ Substitution } \\
\hline 0 & $355.62 \pm 16.15 b c$ & $703.46 \pm 15.66 \mathrm{ab}$ & $55.04 \pm 1.63 \mathrm{a}$ & $47.14 \pm 1.42 \mathrm{a}$ & $153.75 \pm 3.89 \mathrm{a}$ & $26.25 \pm 0.35 \mathrm{a}$ & $-1.25 \pm 10.25 a$ \\
\hline 5 & $339.77 \pm 10.42 \mathrm{c}$ & $620.94 \pm 20.50 \mathrm{~d}$ & $52.74 \pm 0.40 \mathrm{~b}$ & $46.11 \pm 0.72 \mathrm{ab}$ & $152.08 \pm 3.89 \mathrm{a}$ & $19.92 \pm 2.71 b$ & $0.75 \pm 4.36 \mathrm{a}$ \\
\hline 10 & $364.43 \pm 16.00 b$ & $642.71 \pm 22.00 \mathrm{~cd}$ & $51.07 \pm 0.33 c$ & $44.91 \pm 0.90 \mathrm{bc}$ & $150.08 \pm 2.71 \mathrm{a}$ & $17.42 \pm 3.65 b c$ & $-4.25 \pm 4.60 \mathrm{a}$ \\
\hline 15 & $375.20 \pm 11.94 b$ & $680.23 \pm 37.06 \mathrm{bc}$ & $49.27 \pm 1.07 \mathrm{~d}$ & $43.60 \pm 0.51 \mathrm{~cd}$ & $141.75 \pm 2.47 b$ & $16.75 \pm 2.24 b c$ & $-0.25 \pm 4.12 \mathrm{a}$ \\
\hline 20 & $426.57 \pm 16.43 \mathrm{a}$ & $737.07 \pm 30.72 \mathrm{a}$ & $48.22 \pm 1.46 \mathrm{~d}$ & $42.62 \pm 0.77 \mathrm{~d}$ & $134.92 \pm 2.95 \mathrm{c}$ & $14.58 \pm 6.01 \mathrm{c}$ & $-2.42 \pm 1.77 \mathrm{a}$ \\
\hline
\end{tabular}

Results are showed separate effects of drying methods and substitution rates of purple carrot powders which were added based on the wheat flour used (\% (by mass), dry basis). Results are expressed as mean value \pm s.d. Different superscripted lowercase letters in the same column denote significant differences according to the Student's test ( $\mathrm{p}<0.05$ ).

1: Volume Index, 2: Symmetry Index, 3: Uniformity Index.

Table 5. Chemical composition of purple carrot substituted cake samples produced by different drying methods and substitution rates

\begin{tabular}{lcccccc}
\hline & Moisture (\%) & Ash (\%) & Crude Fat (\%) & Crude Protein (\%) & TPC $\mathbf{( g ~ G A E / k g ) ~}$ & Antioxidant activity (\%) \\
\hline Drying Method & & & & & \\
HPC & $24.80 \pm 0.89 \mathrm{a}$ & $1.70 \pm 0.04 \mathrm{a}$ & $16.80 \pm 0.60 \mathrm{~b}$ & $9.34 \pm 0.43 \mathrm{a}$ & $63.05 \pm 3.83 \mathrm{a}$ & $45.64 \pm 0.35 \mathrm{c}$ \\
MPC & $22.88 \pm 1.52 \mathrm{~b}$ & $1.72 \pm 0.02 \mathrm{a}$ & $18.59 \pm 0.12 \mathrm{a}$ & $9.14 \pm 1.35 \mathrm{a}$ & $52.97 \pm 5.98 \mathrm{~b}$ & $52.53 \pm 0.31 \mathrm{~b}$ \\
VPC & $23.29 \pm 1.76 \mathrm{ab}$ & $1.73 \pm 0.02 \mathrm{a}$ & $18.58 \pm 0.24 \mathrm{a}$ & $9.21 \pm 0.15 \mathrm{a}$ & $57.30 \pm 3.76 \mathrm{~b}$ & $57.99 \pm 0.42 \mathrm{a}$ \\
\hline Substitution Rate & & & & & \\
0 & $24.14 \pm 2.58 \mathrm{a}$ & $1.52 \pm 0.04 \mathrm{e}$ & $18.27 \pm 0.17 \mathrm{ab}$ & $9.24 \pm 0.06 \mathrm{a}$ & $22.38 \pm 2.09 \mathrm{e}$ & $24.26 \pm 0.10 \mathrm{e}$ \\
5 & $23.09 \pm 1.52 \mathrm{a}$ & $1.61 \pm 0.02 \mathrm{~d}$ & $18.45 \pm 0.54 \mathrm{a}$ & $9.42 \pm 0.58 \mathrm{a}$ & $37.13 \pm 3.71 \mathrm{~d}$ & $36.82 \pm 0.24 \mathrm{~d}$ \\
10 & $23.64 \pm 0.42 \mathrm{a}$ & $1.72 \pm 0.01 \mathrm{c}$ & $18.16 \pm 0.53 \mathrm{ab}$ & $9.57 \pm 0.82 \mathrm{a}$ & $57.22 \pm 5.22 \mathrm{c}$ & $55.13 \pm 0.59 \mathrm{c}$ \\
15 & $23.30 \pm 1.77 \mathrm{a}$ & $1.81 \pm 0.03 \mathrm{~b}$ & $17.72 \pm 0.25 \mathrm{bc}$ & $9.00 \pm 0.68 \mathrm{a}$ & $75.74 \pm 2.20 \mathrm{~b}$ & $68.25 \pm 0.42 \mathrm{~b}$ \\
20 & $24.10 \pm 0.65 \mathrm{a}$ & $1.93 \pm 0.04 \mathrm{a}$ & $17.36 \pm 0.11 \mathrm{c}$ & $8.92 \pm 1.07 \mathrm{a}$ & $96.39 \pm 9.39 \mathrm{a}$ & $75.78 \pm 0.45 \mathrm{a}$ \\
\hline
\end{tabular}

Results are showed separate effects of drying methods and substitution rates of purple carrot powders which were added based on the wheat flour used (\% (by mass), dry basis). Results are expressed as mean value \pm s.d. Different superscripted lowercase letters in the same column denote significant differences according to the Student's test ( $\mathrm{p}<0.05$ ). 1: Total Polyphenolic Content. 
The TPC of the cakes produced with MPC and VPC were found to be statistically similar. However, the TPC of samples produced with HPC was found to be significantly higher than others. According to the TPC results, the significant differences between all substitution rates were determined by the Student's multiple comparison test. The TPC of samples produced with the higher substitution rates were found to be significantly higher than those lower rates. The drying method used in PCP production significantly affected the antioxidant activity of cake samples. The highest antioxidant activity was found in samples produced with VPC (57.99\%), while the lowest in samples produced with HPC (45.64\%). As the TPC of samples produced with higher substitution, rates were higher than the lower rates, the antioxidant activity was also found to be high. These results were in agreement with a previous study made by Yilmaz and Pekmez (2020) who found that both TPC and antioxidant activity value increased significantly based on increased addition ratio of the purple carrot flour.

\section{Sensory Evaluation}

Sensory analysis results of cake samples are presented in Figure 1. Generally, all tested sensory factors of cake samples prepared using HPC were more appreciated by the panelist. Color, appearance and overall acceptability values of all cake samples were positively affected by high ratios of PCP regardless of the drying method used. Taste and odor scores of cake samples were increased with the higher ratios of MPC and VPC used, while decreased with HPC. Pore structure and chewiness scores of cakes produced with HPC were found higher than those of MPC and VPC. The utilization of HPC in cake formulations presented closer sensory scores to the control sample. $15 \%$ and $20 \%$ substitution rate of HPC and VPC increased the overall acceptability of cake samples.

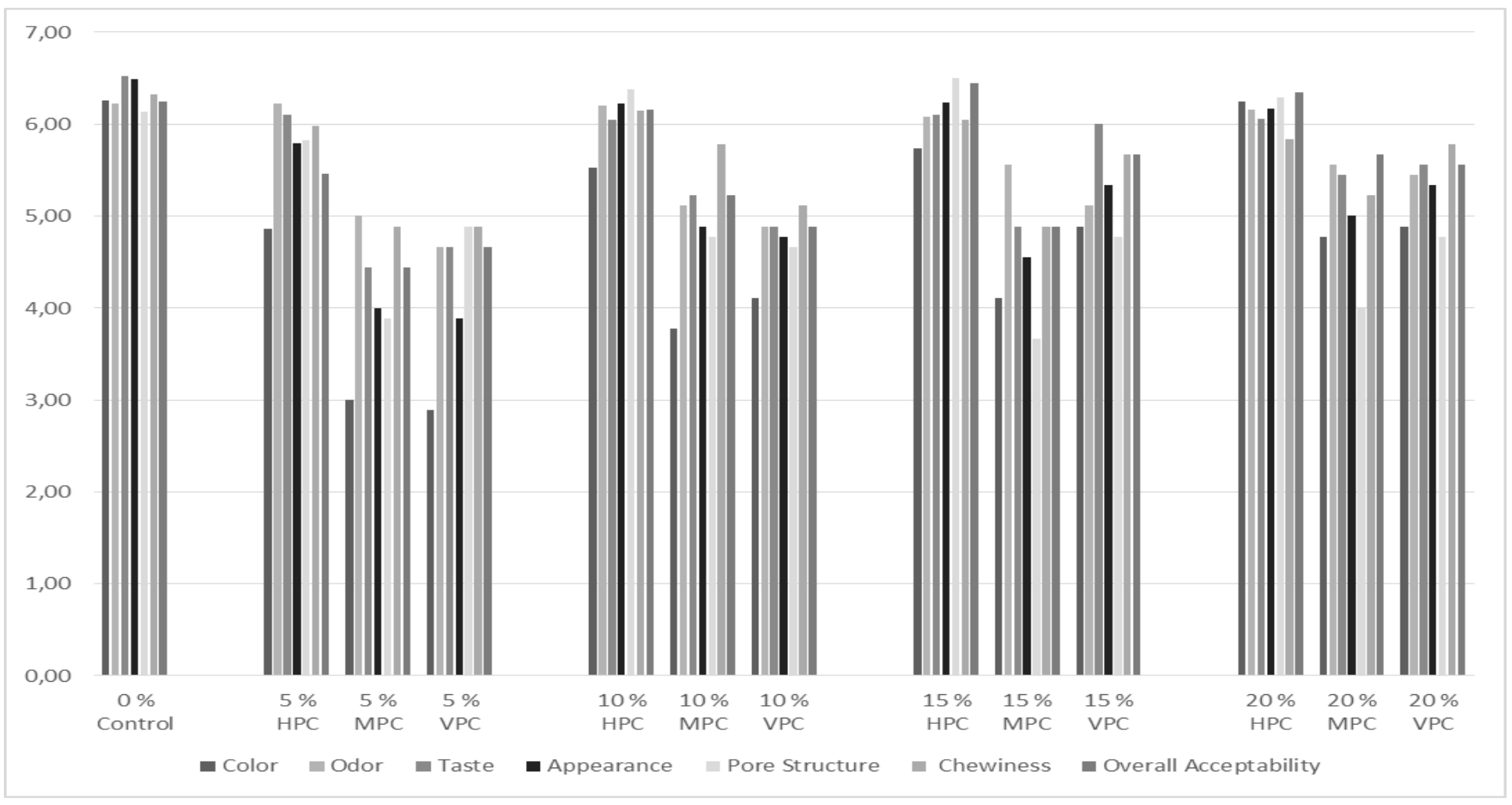

Figure 1. Sensory evaluation results of cakes substituted with purple carrot powder 


\section{Conclusion}

The functional food market is increasingly growing due to enhanced customer interest. Therefore, it was aimed to utilize purple carrot powder obtained by different drying methods in cakes to develop a novel functional bakery product in this study. Obtained results showed that the nutritional characteristics of cake samples were significantly affected by both of the substitution rates and drying methods used of purple carrot powders. The total phenolic content and antioxidant capacity accordingly the functional properties of cakes were increased with increasing purple carrot powder rates. Also, the utilization of purple carrot powder in cakes resulted in higher preferences. In addition, microwave and vacuum drying may see as alternative methods to obtain purple carrot powder.

\section{Compliance with Ethical Standard}

Conflict of interests: The author declares that for this article they have no actual, potential or perceived conflict of interests.

Ethics committee approval: The authors declare that this study does not require ethical permission.

Funding disclosure: -

Acknowledgments: -

Disclosure: -

\section{References}

Alibaş, I. (2009). Microwave, vacuum, and air drying characteristics of collard leaves. Drying Technology, 27(11), 1266-1273.

https://doi.org/10.1080/07373930903267773

AACC, American Association of Cereal Chemists, (1990). Approved methods of the AACC, 11th ed., St. Paul, MN, USA.

Arslan, D., Özcan, M.M. (2011). Dehydration of red bellpepper (Capsicum annuum L.): change in drying behavior, colour and antioxidant content. Food and Bioproducts Processing, 89(4), 504-513.

https://doi.org/10.1016/j.fbp.2010.09.009

Beta, T., Nam, S., Dexter, J.E., Sapirstein, H.D. (2005). Phenolic content and antioxidant activity of pearled wheat and roller-milled fractions. Cereal Chemistry, 82(4), 390393.

https://doi.org/10.1094/CC-82-0390
Chen, X., Li, X., Mao, X., Huang, H., Miao, J., Gao, W. (2016). Study on the effects of different drying methods on physicochemical properties, structure, and in vitro digestibility of Fritillaria thunbergii Miq. (Zhebeimu) flours. Food and Bioproducts Processing, 98, 266-274.

https://doi.org/10.1016/j.fbp.2016.01.008

De Pilli, T., Giuliani, R., Derossi, A., Severini, C. (2014). Development of Maillard reaction in pasta dried by microwaves. Italian Journal of Food Safety, 26(2), 183-189.

Di Scala, K., Crapiste, G. (2008). Drying kinetics and quality changes during drying of red pepper. $L W T-$ Food Science and Technology, 41(5), 789-795.

https://doi.org/10.1016/j.lwt.2007.06.007

Gao, L., Wang, S., Oomah, B.D., Mazza, G. (2002). Wheat quality: antioxidant activity of wheat millstreams. In P. $\mathrm{Ng} \&$ C.W. Wrigley (Eds.), Wheat quality Elucidation. (p. 219233). St. Paul, MN, USD: AACC International.

Gómez, M., Ruiz, E., Oliete, B. (2011). Effect of batter freezing conditions and resting time on cake quality. $L W T-$ Food Science and Technology, 44(4), 911-916.

https://doi.org/10.1016/j.lwt.2010.11.037

Gyamfi, M.A., Yonamine, M., Aniya, Y. (1999). Free-radical scavenging action of medicinal herbs from Ghana: Thonningia sanguinea on experimentally-induced liver injuries. Vascular Pharmacology, 32(6), 661-667.

https://doi.org/10.1016/S0306-3623(98)00238-9

Hosseini Ghaboos, S.H., Seyedain Ardabili, S.M., Kashaninejad, M. (2018). Physico-chemical, textural and sensory evaluation of sponge cake supplemented with pumpkin flour. International Food Research Journal, 25(2), 854-860.

Işık, N.I.E., Izlin, N. (2014). Effect of different drying methods on drying characteristics, colour and microstructure properties of mushroom. Journal of Food and Nutrition Research, 53(2), 105-16.

Jangam, S.V. (2011). An overview of recent developments and some R\&D challenges related to drying of foods. Drying Technology, 29(12), 1343-1357.

https://doi.org/10.1080/07373937.2011.594378

Jyotsna, R., Sai Manohar, R., Indrani, D., Venkateswara Rao, G. (2007). Effect of whey protein concentrate on the rheological and baking properties of eggless cake. International Journal of Food Properties, 10(3), 599-606. 
https://doi.org/10.1080/10942910601048986

Lertittikul, W., Benjakul, S., Tanaka, M. (2007). Characteristics and antioxidative activity of Maillard reaction products from a porcine plasma protein-glucose model system as influenced by pH. Food Chemistry, 100(2), 669-677.

https://doi.org/10.1016/j.foodchem.2005.09.085

Majzoobi, M., Poor, Z.V., Jamalian, J., Farahnaky, A. (2016). Improvement of the quality of gluten-free sponge cake using different levels and particle sizes of carrot pomace powder. International Journal of Food Science \& Technology, 51(6), 1369-1377.

https://doi.org/10.1111/ijfs.13104

Methakhup, S., Chiewchan, N., Devahastin, S. (2005). Effects of drying methods and conditions on drying kinetics and quality of Indian gooseberry flake. LWT-Food Science and Technology, 38(6), 579-587.

https://doi.org/10.1016/j.lwt.2004.08.012

Pere, C., Rodier, E. (2002). Microwave vacuum drying of porous media: experimental study and qualitative considerations of internal transfers. Chemical Engineering and Processing, 41(5), 427-436.

https://doi.org/10.1016/S0255-2701(01)00161-1

Rahmati, N.F., Tehrani, M.M. (2014). Influence of different emulsifiers on characteristics of eggless cake containing soy milk: modeling of physical and sensory properties by mixture experimental design. Journal of Food Science and Technology, 51(9), 1697-1710.

https://doi.org/10.1007/s13197-013-1253-y

Salehi, F., Kashaninejad, M., Akbari, E., Sobhani, S.M., Asadi, F. (2015). Potential of sponge cake making using infrared-hot air dried carrot. Journal of Texture Studies, 47(1), 34-39.

https://doi.org/10.1111/jtxs.12165

Sharoba, A.M., Farrag, M.A., Abd El-Salam, A.M. (2013). Utilization of some fruits and vegetables waste as a source of dietary fiber and its effect on the cake making and its quality attributes. Journal of Agroalimentary Processes and Technologies, 19(4), 429-444.

https://doi.org/10.21608/jfds.2013.72084

Türkyılmaz, M., Yemiş, O., Özkan, M. (2012). Clarification and pasteurisation effects on monomeric anthocyanins and percent polymeric colour of black carrot (Daucus carota L.) juice. Food Chemistry, 134(2), 1052-1058.

https://doi.org/10.1016/j.foodchem.2012.03.013

Uribe, E., Vega-Gálvez, A., García, V., Pastén, A., López, J., Goñi, G. (2019). Effect of different drying rates on phytochemical content and amino acid and fatty acid profiles of the green seaweed, Ulva spp. Journal of Applied Phycology, 31(3), 1967-1979.

https://doi.org/10.1007/s10811-018-1686-9

Yerima, S.M., Saurabh, C., Ibrahim, B., Shahid, K.M., Harshita, J., Nitin, N., Vikas, J. (2019). Hearbal detox extract formulation from seven wonderful natural herbs: garlic, ginger, honey, carrots, aloe vera, dates, \& corn. Asian Journal of Pharmaceutical Research and Development, 7(3), 22-30. https://doi.org/10.22270/ajprd.v7i3.485

Yılmaz, B.B., Pekmez, H. (2020). Quality characteristics and antioxidant properties of bread incorporated by black carrot (Daucus carota ssp. sativus var. atrorubens alef) fiber. Gida, 45(2), 290-298.

https://doi.org/10.15237/gida.GD19134

Zadernowski, R., Pilat, B., Czaplicki, S., Ogrodowska, D. (2010). Characteristics of the black carrot (Daucus carota ssp. sativus var. atrorubens Alef.). Polish Journal of Natural Sciences, 25(4), 438-443.

https://doi.org/10.2478/v10020-010-0040-8

Zhang, M., Tang, J., Mujumdar, A.S., Wang, S. (2006). Trends in microwave-related drying of fruits and vegetables. Trends in Food Science and Technology, 17(10), 524534.

https://doi.org/10.1016/j.tifs.2006.04.011 